\title{
A South-South Dialogue: A Sociological Reflection on Relations between New Zealand and Brazil
}

TOM DWYER

\section{Introduction}

Historians have reconstructed various links, whether empirical or theoretical, between the settler societies of Latin America and Oceania. Between 1787 and 1856 over 800 British boats stopped in Rio de Janeiro on their way to the South Pacific, especially to Australia and New Zealand. ${ }^{1}$ On board were the explorers, scientific expeditions, convicts, immigrants, artists and preachers who came to forge new societies and supply images of a world with vast new frontiers. The earliest exports from Brazil were tobacco, sugar-cane, alcohol, coffee and sugar. Plants and animals were transferred in both directions across the Pacific. Contacts waned after changes in maritime technology and the building of the Panama Canal.

In the words of Fernando Henrique Cardoso, a sociologist and then senator for São Paulo state, the development of the trans-polar air-routes subsequent to the Malvinas war can be seen as a pivotal point for a new period of 'South-South dialogue'. ${ }^{2}$ The main section of this paper will analyze this 'South-South dialogue' from the viewpoint of contemporary globalization. I will employ Michel Wieviorka's classification that emphasizes three distinct dimensions to globalization: economic, cultural and supranational organization to analyze relations between Brazil and New Zealand from 2001 to the present day. ${ }^{3}$ We will see the building of a range of new South-South dialogues as the forces of globalization play their unexpected and surprising hand. In concluding, I speculate about the future and reflect briefly upon two events that resulted in the projection of New Zealand in the Brazilian media.

\section{The present period}

Over recent years global flows of commerce and finance have increased exponentially, communications and images of all types hurtle around the world at what seem to be ever increasing speeds and volumes. At the same time we observe that nation states exhibit limitations in being able to deal with many new questions that arise as a result. All of this has been made 
even more complex, since the end of 2008 , by the global financial crisis. This, while it weakens the principal industrialized economies, and appears to be far from over, has been accompanied by a surprising resilience in some developing economies. In this way, the rise of China and of the BRICs (Brazil, Russia, India and China), projects Brazil onto the world stage in a way unimaginable a decade ago.

Wieviorka characterizes globalization as having three relatively autonomous and distinct dimensions: economic exchanges, cultural exchanges and supra-national organization. ${ }^{4}$ Such a view of globalization helps us to overcome economic determinism, which had, by the end of the twentieth century, become the dominant public policy and even political paradigm in many countries and social sciences disciplines. Such a paradigm sees economic relations as driving all other relations between peoples. By giving a degree of autonomy to the cultural and the supra-national spheres, it is possible to focus appropriate attention on the role of non-economic factors in contemporary social change.

\section{The supra-national sphere}

Direct diplomatic representation between our two countries is very recent. Brazil opened its embassy in Wellington in 1997, while New Zealand first installed a consulate in São Paulo in 1999 and two years later opened an embassy in Brasília. Over recent years an increasing number and variety of official contacts have been promoted between both countries. Thus Cardoso's 1983 hypothesis of a new type of 'South-South dialogue' is being confirmed through official channels.

In welcoming Helen Clark to lunch on November $20^{\text {th }} 2001$, after she had opened the new embassy, Brazil's president Fernando Henrique Cardoso emphasized the links between the two countries, both past and present. ${ }^{5} \mathrm{He}$ mentioned military co-operation in Italy during the Second World War, where 'heavy losses were suffered in defending common ideals' and Timor Leste where, over a half a century later, under a United Nations mandate, both countries had again come together 'defending peace and promoting nation building'. He went on to state that 'the distance which separates us is a geographical contingency, the values that bring us together are universal'.

Most of this speech focussed on international co-operation and identification of common viewpoints in the ecological, peace, economic and scientific areas - given the occasion, it is understandable that there was no reference to differences and potential conflicts between the nations. Some of the major areas of contact in the supra-national sphere between the two countries are outlined below:

1. The New Agenda Coalition for nuclear disarmament was established by New Zealand and Brazil, together with Egypt, Ireland, Mexico, South 
Africa, and Sweden. This group aims to have a series of practical nuclear disarmament measures put in place that go beyond simply reducing the size of arsenals. ${ }^{6}$ New Zealand's position on nuclear disarmament issues is relatively simple; Brazil's agenda is far more complex, fruit of the culture that was built up in the past. Brazil had resisted signing the nuclear non-proliferation treaty for many years because it saw, in the arms race, that the nuclear powers were not adhering to their promises. To exclude a nuclear option, whilst others exercised it, would be to accept an inferior status and also undermine the country's ability to protect its own interests. The Argentinean and Brazilian military had a long history rivalry that hinged around the idea of 'mutual threat' and resulted in distrust of each other's intentions. As Vargas states, '[t]he two countries always defended the principle of the right of access to all nuclear technology for pacific objectives, including access to nuclear explosives for exclusively pacific use, with the controls necessary to guarantee that there can be no chance of the material ending up being used for non-pacific ends'? The controls are found in the Treaty of Tlatelolco ${ }^{8}$ (Treaty for the Prohibition of Nuclear Weapons in Latin America and the Caribbean), which came into effect in 1969. In 1991 the BrazilianArgentine Agency for Accounting and Control of Nuclear Materials was created by the Brazilian and Argentinean governments to verify the pacific use of nuclear materials capable of being used to manufacture of weapons of mass destruction. ${ }^{9}$ As a result of this historical legacy, it was only in 1997, over a decade after the end of military government, that Brazil signed the nuclear non-proliferation treaty.

2. Both countries are a part of the Cairns group and seek fairer and more equal conditions for agricultural trade. Furthermore, they have worked together around their shared interest in the Doha round. The two countries have, however, different positions on industrial protection, although Brazil is not very explicit about its protectionism. In Brazil there is a shared acknowledgment of the need to protect local industry, a legacy of a period of import substituting industrialization policy. The various interest groups established around the industrial economy remain strong today whereas, in New Zealand, the economic base of these same interests was largely destroyed by past inefficiencies and by the economic reforms known as 'Rogernomics'.

3. On whaling the two countries appear to have similar positions as is evidenced by the website of the New Zealand Embassy in Brasilia. ${ }^{10}$

4. Both countries have bases in the Antarctic and are signatories to treaties. Whereas New Zealand assumes quite an important role over 
a range of issues, Brazil's role still remains relatively small, reflecting neither the country's size nor its importance as the Southern hemisphere's largest and wealthiest country.

5. Climate change issues see a coincidence of viewpoints; however conflicts exist around carbon credits trading and details of the Convention on Biodiversity.

6. Perhaps the most immediately identifiable area of potential conflict is around the sovereignty of the Malvinas Islands. Here, further tensions between Argentina and Great Britain remain a real possibility and any repetition of the position taken by New Zealand in the 1980s would be contrary to the country's interests in developing deeper ties with Latin America.

There are of course a series of international organizations, United Nations (UN) agencies, interventions, tribunals and treaties where officials from the two countries work together. A deeper analysis of the differences and affinities in both positions and work styles in these forums is of more than mere academic interest but is beyond the scope of this essay.

Outside of the area of government-to-government relations we can identify other areas of supra-national organization and co-operation. These usually do not interest academic specialists in the area of international relations. The World Social Forum (WSF) is a meeting-ground between many NonGovernment Organizations (NGOs) that seek an alternative approach to globalization. As the space occupied by indigenous movements increases in the forum we can expect to see greater dialogue between Maori and Latin American native peoples. However, social movements from Oceania do not currently seem to play a very active role in the WSF. Also, the New Zealand branch of the Worldwide Fund for Nature (WWF) works with fishermen in Brazil to identify and protect marine turtle nests. However, in my research for this paper I was unable to discover further specific information about co-operation between NGOs therefore it is difficult to ascertain potential synergies and emerging fields of co-operation, as well as potential conflicts, with any degree of ease.

Latin American Solidarity committees played a political and consciousnessraising role in New Zealand in the 1970s and 1980s, however these seem to have all but disappeared as democracy has consolidated in the region. Today, some New Zealand activists support left wing causes such as the governments of Cuba, Venezuela and Bolivia. On a very different note, organized international crime is another area of potential co-operation between private individuals, but I was unable to find any evidence of this. Both governments are involved in efforts to monitor and combat such a development. 
The oldest supra-national organization in the world, the Roman Catholic Church, has played a role in bringing New Zealand and Brazil closer together. Nearly 30 years ago a decision was taken in Rome to establish the Marist Fathers in Brazil (the Marist brothers, a different institution, has been in Brazil for over a century). New Zealanders played a major role establishing the two houses which exist to this day, one in the interior of Bahia state and the other a university chaplaincy in Curitiba, the capital of Paraná state. These missions have brought a few new vocations into the order that had been losing members over the last few decades. Queenstown's large Brazilian migrant population has not been ignored by the Catholic Church. A New Zealand priest who has returned home after having worked for decades in Brazil conducts mass there in Portuguese once a month.

As I hope I have been able to show, there is a lot more to supra-national relations between our two countries than is conventionally placed under the umbrella of 'international relations'. My research on this issue leads to the conclusion that the more relations between the two countries intensify, the more the actors will refer to shared values and, at the same time, will become aware of the differences that separate us.

\section{Economic relations}

Economic relations between New Zealand and Brazil are conducted within three different macro level contexts: firstly, that of international business in and with Brazil; secondly, that of New Zealand business specifically in Brazil; and thirdly, of Brazilian business in New Zealand.

Nearly all of the traditional Fortune 500 companies are present in Brazil, an indication that, in spite of all the rhetoric about the difficulties of doing business in the country, these successful companies have not been put off. In fact, many of them have been there for over 50 years. Until the setting up of the New Zealand Consulate in São Paulo in 1997, and the Embassy in Brasília in 2001, there was no government agency capable of providing often crucial official support in prospecting and closing deals involving New Zealand firms. Also, the guidance previously available was not of the same standard as seen today. ${ }^{11}$ As a result, New Zealand's participation today in Brazil's total bi-lateral (visibles) trade is about $0.05 \%$ (one twothousandth)..$^{12}$

This lack of N.Z. presence can be usefully contrasted with that of Sweden. Swedish companies traded with Brazil in the nineteenth century. Ericsson made the first direct Swedish investments in the 1920s and today there are around 200 Swedish companies active in Brazil. The São Paulo metropolitan area is Sweden's second most important industrial city after Gothenburg. Swedish interests in Brazil are very strong, and even that country's Queen Silvia is Brazilian born! 
The first and most obvious point to be made about commercial relations is that Brazil is quite different to New Zealand. History, language, size, colonization, degree of economic development, culture and inequality are just some of the immediately visible dimensions of these differences. For many New Zealand businesspeople the sense of fundamental differences is not to be found in such visible dimensions, but rather in the regulatory and tax structure. Both dimensions are included in the World Bank's 'ease of business index'. ${ }^{13}$ Out of 183 countries treated in the 2010 index, New Zealand is in second position, lying just behind Singapore, while Brazil is in 129th position! However, all BRIC economies exhibit relatively difficult business climates: China is 89th, Russia 120th and India 133rd. The only country in the world with a land area of over 3 million square kilometres and a population greater than 150 million that is considered relatively friendly is the United States - the country that plays the dominant role in defining the rules for world trade, including deciding what constitutes a friendly business environment.

Small countries like New Zealand are obliged to compete hard for investments and so, in many of them, politicians have come to believe that being agile and business friendly is necessary, especially in countries where the political classes are favourable to economic globalization. Decision makers in large countries frequently perceive that because of their size they have a lot to offer business, and therefore see little need to be 'friendly' in order to attract investments. In fact, being unfriendly can be justified as playing an important role in separating desirable from undesirable investors, those who really want to be present are favoured over those who want to make quick money.

In this way, the size factor is a non-convergent element in BrazilNew Zealand relations. New Zealand will probably always be a very small economic player in Brazil, whereas Brazil has the potential to be a proportionally far larger economic player in New Zealand. Because of the size of its market, demographics, political stability and natural resources, Brazil will probably continue to be a powerful magnet for global capital. It is a market in which New Zealand businesses will have to compete on the terms laid down. The structural disadvantages facing those who come from a small and open economy, where people are blinded by assumptions commonly held in the Anglo-world (such as that the English language serves a universal means of communication, or the innate superiority of both free markets and common law) are obstacles to be overcome.

A few Brazilian investors have been attracted to New Zealand by the lifestyle or the business climate. Interviewees and web searches revealed a variety of mainly small enterprises. We find Brazilians involved in building, hospitality, tourism, ${ }^{14}$ and importing (of both traditional products such as 
cachaça (sugar-cane rum) and coffee, and non-traditional products, such as fashion). In April 2010 Petrobras gained the right to explore for oil off the East Coast of the North Island for a five-year period. New Zealand Trade and Enterprise's 'Brazil country report' site talks of $\$ N Z 5,000,000$ being invested by Brazilian firms in New Zealand, and of only \$NZ1,000,000 invested by New Zealand firms in Brazil in the year 2002. ${ }^{15}$ Brazilian figures for New Zealand direct investment put their value at \$US66,000,000 between 2005 and 2009. ${ }^{16}$ The New Zealand Reserve Bank proved unable to provide a similar figure.

New Zealand's commercial performance in Brazil appears, in the words of one of my interviewees, to have been 'pretty dismal.' The tremendous opportunities for growth in trade seen in the period subsequent to the reopening of the trans-polar air route in 1983 did not seem, in the words of the former New Zealand honorary consul Brian Sinclair, 'to have amounted to much.' The economic dimension of the South-South dialogue, except for sporadic and momentary New Zealand successes such as dairy exports in the 1980s and early 1990s, seems to favour Brazil which had a positive trade balance over five years during the 1990s and over all years during the decade since $2000 .{ }^{17}$

Is such a picture accurate? If so, what is going wrong? If not, what is going on? In order to try formulate an answer to these questions, and to treat other important dimensions of New Zealand-Brazil relationships adequately, I read reports, consulted statistics, relied on personal observations and many conversations during a period of over 25 years living in Brazil. Furthermore, I conducted a series of lengthy interviews with seven long-term resident New Zealand entrepreneurs involved in successful ventures in Brazil, with a further two people predominantly involved in the cultural area and also with four Brazilian and New Zealand diplomats. Entrepreneurial informants had over 120 years of combined experience in the Brazilian market. I tried to identify key ingredients of the failures of New Zealand companies. ${ }^{18}$

Interviews led to the following formulation of what makes for an unsuccessful New Zealand business venture in Brazil. Firstly, not being prepared for a long-term relationship - those interested in short term gains make mistakes easily and quickly become discouraged. Making the decision not to live in Brazil and not to learn the language has a significant impact, creating the need for a local counterweight and requiring, in turn, extremely careful selection of a representative and of local staff. Unsuccessful entrepreneurs often take poor advice, and refuse to listen to sound advice that goes against one's preconceived notions. ${ }^{19}$ A lack of detailed market and product research impact greatly on success or failure, as does a lack of attention to details, especially to the complex regulatory environment (tax laws, tariffs, customs procedures, state and local body laws, the protection 
of intellectual property etc). It is important to recognize that there exists what can be typified as an 'oriental element' to Brazilian bureaucratic culture, hence specialists who can guide one about how to 'work the system' (for example, despachantes and lawyers) can lubricate operations. Lack of adequate capital to survive the long and complex implantation process also plays a part, so too does lack of care in the hiring of management staff.

Interviewees revealed cases of foreign companies and entrepreneurs (not only of New Zealanders, but nearly always of English speakers) that had decided to invest in Brazil but, having made only one of these mistakes, had failed. I asked interviewees whether the avoidance of these 'do nots' was not simply good business practices. The answer was in the affirmative but, it was explained, processes move slowly in Brazil which can lead to impatience and a desire to cut corners. What follow may be fatal errors. Trying to bribe one's way through bureaucratic obstacles instead of trying to resolve them by talking to the pertinent people and being patient is a case in point. From a pragmatic viewpoint, corruption may resolve some short-term problems but can provide powerful incentives for others, further down the track, 'to build obstacles in order to sell solutions'. When difficulties arise, it is wise to avoid confrontation, to seek accommodation, an example of yet another 'oriental' element of Brazilian culture. In many situations it is better to avoid direct confrontation, to say 'we shall see' rather than 'no'.

Having made these points we can now move forward. There are New Zealand products, companies and businesspeople in Brazil which have done well, and others which have done extremely well:

1. In the export sector wines, electronics, ${ }^{20}$ farming equipment and farm inputs, from semen to seeds, ${ }^{21}$ are among the (non-dairy related) goods that have contributed an average of $\$$ US39,000,000 per annum to New Zealand's overseas accounts over the 2002-2009 period (Brazilian exports to New Zealand averaged \$US71,000,000 per annum over the same period).

2. In education and tourism, sectors that are far less regulated than manufacturing and agriculture, receipts are more significant than with 'visibles' trade. Brazil is New Zealand's eighth most important educational market, and in 2008-2009 it is estimated to have earned, at the very least, \$NZ57 million. Brazilian tourist numbers to New Zealand have been growing at $18 \%$ a year over the last five years. 11,500 visitors came to New Zealand in 2008-2009, earning an estimated \$NZ27 million annually.

3. In the service sector, from telephone services to the hospitality trades, important examples of success can be found. One New Zealand-run telephone services company has a three-year contract worth \$US50 million. 
4. We also find direct investment by New Zealand companies. Undisputedly the most important of these has been Fonterra's joint venture with Nestlé, 'Dairy Partners of the Americas' (DPA). Operating since 2003, DPA specializes in processing and processed 2.1 billion litres of milk in Brazil in 2009. ${ }^{22}$ There have also been direct investments in dairy farming, as land is much cheaper than in New Zealand, animals do not need to be confined, large markets are close by and there is very good rainfall. ${ }^{23}$

Should the basic pitfalls be avoided, entrepreneurial capacity allied with an acute definition of available opportunities seems to be a key to success. When I examine the cultural domain I will refer to cases of New Zealand entrepreneurs who have identified gaps in the market, have been innovators, broken with the prevailing paradigms and, as a result, have redefined the area in which they have invested.

\section{Cultural exchanges}

At the heart of cultural exchanges is communication; it is a functional necessity for life together, and it is also a human value. Information arrives from near and far by person-to-person contact, newspapers, radio, immigration, broadcast and cable television and the internet. As receivers, we try to decode the information received and problems that relate not only to the nature of social reality in other parts of world, but also to the state of communication about such realities become evident. Frequently we have no means of understanding the images, stories and sounds we see and hear. Sometimes this occurs because we have no reason to trust the official versions presented of such events. It is here that the humanities and the journalism profession exert their noble roles, to navigate between the various versions held of the same facts and to permit these to be presented with balance so that they become intelligible to receivers in their own culture.

But communication is not only the transmission of positive cultural images such as ' $100 \%$ Pure New Zealand'. It also includes news about massacres of street children in Brazil, favelas, natural disasters, and, in a turning point in contemporary history, the destruction of New York's Twin Towers which generated images that crossed the whole world in minutes and arrived in the homes of the majority of the world's population within days. The speed of transmission is such that we become dazed, until new images take the place of the old. However, we are so constantly bombarded with new information that it becomes difficult for us as receivers to make sense of the world around us, this produces a chronic condition of contemporary civilization, which Dominique Wolton calls incommunication - the impossibility of communication. ${ }^{24}$ 
Contemporary cultural exchanges between New Zealand and Latin America are, of course, deeply embedded in contemporary information flows. In this section I will select only a few of them: immigration, paradigmbreaking entrepreneurs, scientific and technical exchange and São Paulo city (the place where flows of communications and business join together).

\section{Immigration}

Both our countries are marked by immigration. New Zealand's pool of original European immigrants came predominantly from the British Isles, some after spending time in Australia. Later, small numbers of northern and southern Europeans added to the population. Between the world wars, immigration from the British Isles was privileged and government policy aimed to keep out Chinese, Indian, Dalmatian and Italian migrants. Recent flows of immigrants have contributed to making contemporary New Zealand a far more complex society than it was even three decades ago. Today, and this is a dramatic change from the situation which prevailed up until the 1980 s, there is a substantial Brazilian immigrant presence, making an impact on culture, body language and, of course, the image that New Zealanders have of Brazil. The Brazilian Embassy in Wellington estimates that there are now around 6000 Brazilian residents in New Zealand, ${ }^{25}$ only a tiny fraction of the more than three million Brazilians living outside the country of their birth.

New Zealand immigration to Brazil is extremely limited. For the 1970s there are no reliable estimates of numbers; there were perhaps a dozen New Zealanders in Brazil, and a similar number of Brazilians in New Zealand. Indeed, the numbers of immigrants personally known to core members of each community were even smaller. Today we can talk of perhaps ten times this number. In my evaluation the impact of the New Zealand immigrant community is far greater than their small numbers would lead one to expect. It is also interesting to note that, once they have learnt the language, all New Zealanders emphasize how well they are treated in Brazil on a personal level.

New Zealanders interviewed in Brazil were unanimous about the positive impact for both countries of recent Brazilian migration to New Zealand. The 2010 'Parallel Pasts, Convergent Futures?' conference hosted by the Stout Research Centre and the Victoria Institute for Links with Latin America, showcased a number of bright young Brazilians who were enriching New Zealand's academic culture. As a result of this immigration New Zealand is changing: capoeira and Brazilian Jiu Jitsu are being taught; two Wildfire restaurants in Auckland, using a Brazilian-style 'running spit' system, and a bar in Queenstown combine to bring new flavours and sounds to the country. B Original stores in Auckland and Mount Manganui make Brazilian women's 
fashion available, and original Havaianas sandals (which New Zealanders call 'jandals') are distributed and increasingly worn. Two important visible products of the cultural interchanges have been the CD recording OE Brazil which fuses South-Pacific and Brazilian rhythms and, of course, Wellington's always surprising annual Cuba Street Carnival parade.

\section{Paradigm-breaking New Zealand entrepreneurs}

A major impact of New Zealand immigrants on Brazil has been to see opportunities and to break the paradigms within which day-to-day life, or even life over generations, had been organized in a given area of activity. In so doing, they have worked closely with numerous Brazilians and had an impact on the lives of many more.

As is widely known Brazil's 7.5\% annual growth during the 1947-1980 was a record for a developing country at that time. However, it had the undesirable side effect of a long period of economic instability, with high inflation leading to a series of radical 'stop go' economic plans designed to bring it under control. This meant that planning was next to impossible and not emphasized in most areas of activity. It was in this context that New Zealanders, who brought a 'culture of planning' to an economically stabilized Brazil, had, in the words of one Kiwi businessman, 'an unfair advantage'. Secondly, they brought a capacity to conduct in-depth research into their areas of interest and expertise. The twin capacities of being able to raise adequate capital and of being prepared for a long-term engagement were also found among these innovators. However, a fifth factor proved extremely important, all had a vision. I would now like to give some examples of this kind of paradigm-breaking.

Bahia state in North-eastern Brazil is about twice the area of New Zealand and home to more than 14.5 million people. In its hinterland a greatly impoverished population lives in a semi-arid region. It is in this region that New Zealanders' efforts have probably contributed to directly transforming the lives of the greatest number of Brazilians. Marist Roman Catholic priests led by a New Zealander arrived in the Pindaí area a quarter of a century ago. There they came across small towns where poor small farmers had no irrigation, political power was in the hands of autocratic families who seemed to have ruled forever with an iron hand, no one had a university education and incomes were so depressed that forced migration often appeared to be the only solution for many. Foreign aid supplied by the New Zealand Embassy and further funding from church sources permitted the drilling of a water bore, which led to the first micro-irrigation project in the State. Beehives were introduced and around 30 families organized in a co-operative today collect some 50 tonnes of honey annually, bringing in a family income of approximately $\$ 800$ NZD per month which, in this 
area, is considered to be a fortune. Cultural amenities, such as libraries and even a theatre, were set up for the first time in a number of small towns. In one town of 24,000 residents, no one had ever been to university; today there are about 40 graduates! Even local politics have been affected, as one priest commented: 'They don't kow-tow to the mayor any more'.

Two further examples come from the hospitality trades in São Paulo city. In São Paulo two young 'opportunity seeking' entrepreneurs set up ventures that have been well received in the city's very competitive middleclass market. The first project involved an Irish pub, in the style of the new 'traditional Irish' pubs that Guinness Breweries had been building across Europe in the 1990s. There was nothing like it in the city, and a group of offshore investors made the development possible. Opened by Prime Minister Helen Clark on her only official trip to São Paulo, she emphasized that it was another example of the creativity of Kiwi entrepreneurs. Called the 'All Black Irish Pub', it continues to be packed nine years after opening day. After initial success, the same entrepreneur opened 'Kia Ora', a venue where 500 people can dance to live music all night, and at the same time have a 'down-under experience' in a building that is a copy of a red New Zealand barn. About $20 \%$ of the clients are said to be attracted because of the 'Oz-New Zealand theme' offered and, in return, New Zealand gets free publicity.

Another project, the Santo Grão (Holy Bean) cafe, launched in 2003, today has a total of five branches in the city and about 40 points of sale of its key product. Each branch seats between 90 and 130 clients, opens seven days a week and employs a total of 170 staff. After nearly a year's research, the Kiwi owner realized his original project 'to sell coffee to Brazilians'. The group's first café found inspiration in Wellington's Caffe L'affare. These Santo Grão cafes sell food and other products that the owners have chosen as a function of their own tastes, rather than what they thought customers would like. The choice of staff and location are seen as other factors of success. 'The essence of the concept is very New Zealand . . . we're exporting our culture,' said the proud New Zealand owner.

The culture exported by both of these entrepreneurial groups, is related to a concept and to a built and a service environment, but also there is a culture of staff management. These entrepreneurs report having experienced great difficulties with the low general level of employee education, which leads to low productivity. However, they believe in educating and trusting staff, allocating responsibilities, making sure that people earn well and have even sent their most promising staff to New Zealand for further training. This management culture is credited with making for high levels of staff satisfaction, low employee complaints and happy clients. 
My last case study comes from the dairy industry in Bahia. Set up in an area where land is cheap because it is considered unsuitable for dairy farming - Bahia state is a net importer of milk and milk products- the Leitissimo farm was inaugurated in October 2009 by the New Zealand Minister of Agriculture David Carter. It became a hot topic in the specialized national media, both print and visual. The former Honorary New Zealand consul in São Paulo wrote:

The reasons for the selection of this area were: the climate (altitude of 1000 meters); the virgin soil conditions, which required very little fertilizer and introduction of nitrogen; and the huge volume of underground water, which when pumped through the 400 meter layer of sand which lays beneath the top soil, emerges crystal clear, perfect for human consumption as well as for irrigation and other farming operations . . . ${ }^{26}$

Three 800-hectare circular paddocks were formed to receive pivot irrigation. Cows have been especially bred for local conditions using the most advanced scientific techniques and although, the breed is still unregistered, it is currently nicknamed the 'Kiwi-cross'. After nine years of implantation there are now some 3000 cows that produce 20,000 litres of milk per day, a level of productivity similar to that found in New Zealand. There is room for expansion and the farm will increase greatly in size over the next few years.

Differing from the Brazilian tradition of farm ownership, owners live on the farm, staff live in houses that are the same size and style as those of the owners, and the children all go to the same school together where classes are held in English and Portuguese. Brian Sinclair, who spent over twenty years unsuccessfully trying to persuade Brazilians of the potential rewards to be gained from applying New Zealand farming techniques in Brazil, described the opening as 'the fulfilling of a dream'.

The specialized national media has called the model 'revolutionary', and suggests that its influence may herald profound changes in the Brazilian dairy industry. This 'dream fulfilled' potentially breaks with the paradigm set forth in James Belich's book Replenishing the Earth, indicating a possible new phase. ${ }^{27}$ The question is, are we talking about a new phase of the expansion of Anglo-world pastoralism: science-based, post-industrial, adapted and transported into tropical Iberian America.

To conclude this section, in each of these cases the lives of many Brazilians have been directly transformed as a result of the action of Kiwi immigrants. Staff is managed in a way that emphasizes owner presence, trust, responsibility, dialogue and raising individual competence. The entrepreneurs contrast this 'Kiwi style' with what they see as a 'Brazilian 
style' of management. In the hospitality trade, the premises established and products offered project New Zealand culture and vision to hundreds, perhaps thousands of clients on a daily basis. The awards won by these enterprises provide explicit recognition of their non-commercial dimensions, recognition that they have made important contributions to the quality of premises offered in the city. Brazilian entrepreneurs have been inspired by what has been done and try to copy the style.

\section{Academic and scientific co-operation}

It is useful to see scientific co-operation as a specific form of cultural exchange which is moved by four distinct logics, which combine scientific capacities on the one hand and the construction of scientific problems on the other: firstly, there are areas where complementary and context-dependent interests lead to the development of research co-operation; secondly, scientific co-operation can exist independently of a shared context; thirdly, phenomena observed in one country raises curiosity in another country (without there necessarily being a scientific exchange); and finally, cooperation agreements are made independently of the existence of a scientific problem. A Memorandum of Understanding (MOU) was signed between the New Zealand and Brazilian governments in 2001 around scientific and technological co-operation. However, most co-operation currently takes place between individual researchers and is not dependent on the MOU.

I believe that mistakes and errors teach us much more than successes, so I shall start with the last of the four logics detailed. My university, UNICAMP, and the University of Auckland signed an agreement in 2004, on the occasion of Education Minister Trevor Mallard's visit to Brazil as the Head of an Educational mission. There was no specific scientific problem in mind when the agreement was signed, nor was there any targeted resource allocation in either university. Auckland's primary interest was in student exchanges and the payment of fees. Besides the cases of a few students studying in each institution, nothing else has happened since then. Interests that Brazilian scholars had in New Zealand met with no resonance from New Zealand counterparts, resulting in a 'non-exchange' which left a sour note.

Under the third logic, that of curiosity, we find that a number of Brazilian post-graduate theses have been written on dimensions of New Zealand's economic policies, especially those which have had an influence in Brazil, such as inflation targeting, Reserve Bank autonomy and fiscal responsibility. Brazilian colleagues that work in tourism have spoken with enthusiasm regarding the ' $100 \%$ Pure New Zealand' brand. Issues around Maori have attracted the interest of Brazilian anthropologists, and resulted 
in publications. ${ }^{28}$ In such cases, these interests may eventually turn into exchanges of the first type.

Following the second logic (co-operation independent of shared context), we find research fields that are universal. In an area such as acoustics, for example, scientists can co-operate internationally, and this co-operation has a general impact on the discipline. However, such co-operation rarely goes beyond the relations between individual scientists involved and, as a result, does not lead to any greater density in relations between the countries involved.

The first logic, that of complementary and context-dependent interests, is where we can foresee most co-operation emerging. New Zealand and Brazil have complementary interests around a series of agricultural topics. In the past there was, to give one example, considerable co-operation in grassgrub research in the Rio Grande do Sul state-Uruguay border region, which had implications for New Zealand and vice versa. These days there are a number of ideas brewing about co-operation between the Crown Research Institutes and Brazil's Embrapa. Also, there have already been exchanges around bio-fuels.

An important step towards technical, and to a lesser extent, scientific cooperation was made with the recent signing of a MOU between the Brazilian Environment Ministry and New Zealand's Department of Conservation. One possible result could be the transfer of New Zealand management methods to Brazil's national parks, many areas of which are barred to the public because the local ministry has not acquired adequate management capacities.

In the Antarctic, Brazil is currently a relatively small player given its size and New Zealand is a relatively big one. There are few signs of scientific co-operation, in spite of Brazil's president speaking about this question in welcoming Helen Clark in 2001. The question of the Southern Oceans is a little different; here common scientific questions exist which researchers from both countries co-operate on, independently of government initiatives.

New Zealand has been leading the 'Global Research Alliance' built around another common problem: as the agricultural sector expands to meet growing demand for food, production worldwide is projected to rise $50 \%$ by 2030 , leading to concern over the control of greenhouse gas emissions. The Alliance aims to promote exchange of scientific data on the one hand, and to identify gaps in knowledge on the other. Through these twin strategies, it is hypothesized that a win-win dynamic can be created, contributing simultaneously to the raising of agricultural production and environmental protection. Brazil has been an observer at the meetings held, but is not among the 30 countries that have so far signed up to the Alliance. ${ }^{29}$ Time will tell whether this hesitation is a result of Brazil's identification of a different set of strategic interests to those of Alliance members, or if it is 
the result of slower decision-making processes that operate even when in cases where shared values are identified.

In conclusion, the New Zealand Government's Latin America Initiative web page shows that between July 2007 and April 2008 four initiatives in the agricultural research field were funded by MFAT, of which three involved New Zealand scientists visiting Brazil. In this section, I have tried to give emphasis to the meeting of cultures, of one culture influencing another, through scientific exchange. The impacts of such exchanges are typically either practical (technical) and economic, or intellectual. Today New Zealand life seems to be dominated by market forces and, in such a context, it is necessary for intellectuals to defend the necessity of financing research initiatives that do not reflect purely utilitarian concerns in order to promote understanding. Such a limited agenda risks leaving other interesting questions on the sideline, ones capable of playing an important role in each of the countries as they come to know each other better. Faced with pressures that seek to promote utilitarian objectives, it is necessary to promote the universal values of inquiry and of mutual understanding.

\section{São Paulo city}

New Zealand's trade representation is centred in São Paulo city, whereas diplomatic representation is located in the nation's capital, Brasília. The former is Brazil's financial, intellectual, cultural and industrial capital. The sprawling, unequal and complex city's direct influence extends north to Brazil's frontiers with its Amazon neighbours, eastwards to Santiago de Chile, and to the southernmost tip of Argentina. Undisputedly the leading city in South America, the recent growth of Brazil has seen São Paulo's role in the world economy increase. The city seems destined to assume a central role in South America's insertion into the globalized economy. Its airport is the single most important entry point for New Zealanders arriving in Brazil and São Paulo state is the principal source of students and tourists travelling to New Zealand.

The city has attracted immigrants for over a century; it counts on some of the largest populations outside of their homelands of Italian, Lebanese, Armenian, Japanese and Portuguese descendents. São Paulo city is also the home to many members of Brazil's small New Zealand community. A network of skilled and culturally savvy Kiwi businesspeople, their business partners and trusted colleagues serve as a port of call and of orientation for potential investors and visitors.

\section{The future}

As the Danish physicist Niels Bohr so wisely said: 'Prediction is very difficult, especially if it is about the future'. My two key assumptions in 
making the following predictions are that New Zealand's present government will maintain the general lines of the previous government's Latin American strategy, and that the Brazilian economy and position in the world will continue to strengthen. Here my writing is essentially directed at a New Zealand audience.

On the economic front I imagine that Brazil will continue to be a country of opportunities. 'Business as usual' means continuing to build infrastructure and catering to the needs of an economy that has been averaging $4.5 \%$ annual growth over recent years, and where tens of millions of people have come out of poverty over the last 16 years. Three exceptional opportunities loom large on the immediate horizon: Petrobras plans to make over \$US200 billion in investments over the next five years; the FIFA World Cup will take place in Brazil in 2014; and Rio de Janeiro will host the Olympic Games in 2016. History teaches that not all increased economic contact will necessarily be smooth sailing, as the recent protests in New Zealand against Petrobras' planned operations show.

Today Brazil is the only country in the world that still has a sizeable agricultural frontier that can be opened up. This, and the conversion of existing land use, will continue to open space for the expansion of New Zealand farming techniques, and provide a potential win-win situation for both countries. However, issues surrounding the legitimacy of foreign land ownership, which have recently led to protest in New Zealand, are also present in Brazil, where a restrictive unenforced law has been recently drawn back onto centre stage by a regulatory body.

Unless the views and practices of New Zealand businesspeople change, Brazil will continue to be a land of lost opportunities while Brazilian immigrants to New Zealand will continue to seek out business opportunities. Most non-immigrant Brazilians looking for business opportunities in New Zealand will be likely to adopt a 'regional perspective' that will include Australia.

On the cultural front, two-way flows of people should continue to rise. This will contribute to the transformation of body language, culinary and musical tastes in New Zealand, and of course to partying! Brazilian influences will possibly also feed into New Zealand soccer. The more mixed marriages there are, the more children are born from these, the more a common future will be built. The study of the Portuguese language will increase in New Zealand.

There will probably be increased research ties and comparative research in areas of common concern, whether this will include history and the social sciences will depend on a mixture of academic sensitivities, individual initiatives and of scientific policy decisions. 
São Paulo will continue to be the major point of entry and the most dynamic centre in South America and, for these reasons, will continue to attract Kiwi entrepreneurs. New Zealand entrepreneurs using elements of "blue ocean strategies' ${ }^{30}$ may follow in the footsteps of the pioneers in a variety of areas in the Brazilian economy and in cultural production.

In the area of supra-national organization, there is likely to be an increasing sense of shared interests in certain areas of government-togovernment relations: climate change, agricultural production and market access, whaling, nuclear arms, Southern oceans and the Antarctic. In the areas of intellectual property and industrial protectionism both countries may line up on opposing sides, Brazil aligning with developing countries, and New Zealand with the industrialized countries. NGOs and other nongovernmental supra-national organizations will increasingly interrelate. And it is possible that this will have an effect on relationships between indigenous peoples.

It is likely that conflicts will increase; some of these will have to be administered through diplomatic channels. I have mentioned land ownership issues and Petrobras' oil drilling in New Zealand as examples. I would like to conclude this section with four further insights, the validity of each is based on the coming into being of a prior condition, a necessary, but not a sufficient condition, for validating the insight:

1. Should a direct air-route between Auckland and São Paulo open up - there is a formal agreement in place which permits such a route interviewees thought this would result in increasing exchange and would contribute to altering perceptions about possibilities in Brazil.

2. Should the BRIC hypothesis be confirmed and expand beyond the narrow economic sphere, Brazil is the only BRIC that has a dominant Western cultural tradition. This will become a central reference point in dialogues between the BRICs and the West.

3. Should there be UN reform and the Brazilian demand for a permanent seat on an enlarged Security Council be met, both New Zealand diplomatic endeavours and internationally relevant NGOs will make increasing reference to Brazil.

4. Should further tension emerge around the Malvinas islands, the interpretation made by South American partners of New Zealand's stance will be fundamental in determining the future health of diplomatic and other relations.

\section{Conclusion}

Some thirty years ago New Zealand was a virtually unknown quantity outside of very specific circles in Brazil. Today, this is no longer the case. If 
New Zealand enjoys a very positive image among the Brazilian upper-middle class, and such an impression is shared by all of those who I interviewed in order to write this chapter, ${ }^{31}$ this would appear to be a macro-level impact of many different micro-level phenomena that operate above all at the cultural level. To speak in Weberian terms, the image that New Zealand has projected has demonstrated itself as capable of altering the course of action of (especially upper-middle class) Brazilians, who are not only more aware of the country, but have become attracted to it.

When one looks at the website of the Brazilian Embassy in Wellington, one sees many examples of efforts made to promote understanding by New Zealanders. The New Zealand government has sent journalists to Latin America to learn about this part of the world, with the aim of reducing ignorance about this part of the world at home. To the extent that the images of street children, massacres and corruption are complemented by other images, ones of economic power, public joys and natural beauties, the two countries grow closer together. However, two highly mediatized events took New Zealand into the homes of nearly all Brazilians and, as such, have marked at a symbolic level the coming together, through gestures and blood, of the two nations.

The tragic, and ultimately stupid, death of Sir Peter Blake, at the hands of river pirates near the mouth of the Amazon River, provoked a massive reaction of solidarity and condolences among ordinary citizens in Brazil. It was the most high profile murder of a foreigner in the country over the last decade. The mood behind the popular outpouring was on a scale for which I can think of no historically equivalent parallel.

The second event involved a gesture which occurred in the presidential palace that lies at the centre of Brazil's modernist version of an imperial capital, and was printed on the front page of major Brazilian newspapers. 'He certainly didn't expect it' said a witness to Fernando Henrique Cardoso's reception of the Maori concert party that he had personally invited into the palace on the occasion of Helen Clark's visit. As the president reached out to shake the hand of a member, in a breach of protocol, he was pulled into a hongi. Immediately the flashes went off. The photos that captured the exchange of the breath of life became one of the year's major photos, the incident constituting a tremendous publicity coup for such a small country, and, coming just after the opening of the Embassy, it symbolized new times - indeed, convergent futures - in a 'South-South dialogue'.

1 P. da C. Menezes, O Rio de Janeiro na Rota dos Mares do Sul, Rio de Janeiro, 2004, p.214.

2 T. Dwyer, 'A South-South Dialogue?', New Zealand Listener, 14 May 1983, pp. 88, 94. 


\section{Journal of New Zealand Studies}

3 M. Wieviorka, Neuf leçons de sociologie, Paris, 2008, Chapter 2.

4 This categorization is also quite close to that of Portuguese sociologist, Boaventura de Sousa Santos, who differs in that he sees the categories as interlinked. See his work A Globalização e as Ciências Sociais, São Paulo, 2005.

5 F.H. Cardoso, 'Discurso por ocasião do almoço oferecido em homenagem à PrimeiraMinistra da Nova Zelândia, Senhora Helen Clark', Brasília, 20 de Novembro, 2001. www.biblioteca.presidencia.gov.br/area-presidencia/pasta.2008-10-08.1857594057 /pasta.2008-10-08.9262201718/pasta.2008-12-16.0710539708/pasta.2009-03-05.9736114360 168.pdf, accessed 19 August 2011.

6 www.mfat.govt.nz/Foreign-Relations/1-Global-Issues/Disarmament/0--Nuclear/0-new -agenda-coalition.php, accessed 19 August 2011.

7 E.V. Vargas, 'Átomos na integração: a aproximação Brasil-Argentina no campo nuclear e a construção do Mercosul', Revista Brasileira de Política Internacional, 40, 1 (1997), pp.41-74.

8 www.opanal.org/opanal/tlatelolco/tlatelolco-i.htm, accessed on 19 August 2011.

9 www.abacc.org.br/?page_id=5\&lang=en, accessed 19 August 2011.

10 www.nzembassy.com/brazil, accessed 19 August 2011.

11 Long-term Kiwi residents in Brazil point out that this historical neglect of one of the world's largest economies has contributed to limit the development of New Zealand endeavours.

12 Brazilian bi-lateral trade with the rest of the World (FOB) was \$US370.927 billion in 2008, and with NZ was \$US176.14 million, or about $0.05 \%$.

13 http://data.worldbank.org/indicator/IC.BUS.EASE.XQ.

14 New Zealand tourists travelling to Brazil have also been growing $18 \%$ per annum over the past seven years, statistics available in August 2010 put their numbers at nearly 9,500 per annum.

15 www.nzte.govt.nz/explore-export-markets/south-america/doing-business-in-brazil/pages /brazil-country-brief.aspx, accessed 30 August 2010. I was unable to verify these figures independently and, even if they were accurate, they would be out of date today.

16 www.itamaraty.gov.br/sala-de-imprensa/notas-a-imprensa/visita-ao-brasil-do-ministro -dos-negocios-estrangeiros-da-nova-zelandia-murray-mccully-sao-paulo-13-e-14-de -agosto-de-2010.

17 Based on World Trade Statistics, kindly prepared by Tim King, formerly of NZTE.

18 The process of assembling the evidence from interviews was not as thorough as an academic study deserves and, except for naming one source (Brian Sinclair), who is both a unanimous and a unique historical reference, I have opted to preserve anonymity. I cannot help but think about the benefits of having a post-graduate student or academic specialized in international business conducting in-depth research around this question, in particular employing the case study method to examine notable failures. Such research would complement my analysis with more soundly based knowledge than I have been able to provide on the basis of interviews, however, I do not imagine that such results would contradict my findings.

19 This category is constructed ex post-facto, subsequent to failure. It is therefore difficult to pin down exactly what interviewees mean, since the notions of 'sound advice' and 'poor advice' are constructed only after failure is known about. 


\section{A South-South Dialogue}

20 New Zealand and Brazil: Southern Partners, Wellington, Ministry of Foreign Affairs and Trade, p.7. Tait Electronics, NZ 'offers high technology, for example, though sale of encrypted radio equipment to many Brazilian police forces and other government-linked bodies'. This success story was quoted by all interviewees.

21 T. Cranshaw, 'Seed Potential in Southern Brazil', Press (Christchurch), 17 July, 2009.

22 http://gastronomiaenegocios.uol.com.br/home/tendencias/ver/1156/nestle/imagens/banners /bancoAlimentos.swf, accessed on 30 August 2010.

23 See T. Cranshaw, 'Kiwi Influences on an Emerging Dairy Giant', Press (Christchurch), 18 July, 2009. As mentioned earlier, I was unable to find reliable estimates of the value of these investments.

24 D. Wolton, Informer n'est pas communiquer, Paris, 2009.

25 In the 2006 Census, the usually resident New Zealand population born in Brazil, numbered 1,374 , as against 321 a decade earlier. I thank Prof. Charles Crothers of AUT for these statistics. In addition, in 2008/9, Brazilians were issued 3,159 work permits, 4,446 work and student permits and 166 skilled and business visas. Migration Trends and Outlook 2008/9, DOL, 2009. Available at www.immigration.govt.nz/NR/rdonlyres/232C2841-FECA-4251 -A1AA-F398F82CA5E7/0/LOWRESDOL11130MIGRATIONTRENDS14Jan2010.pdf .

26 B. Sinclair, 'The realization of a dream: New Zealand Dairy Farm in Brazil, Fazenda Leite Verde Marketing UHT Milk "Leitissimo"'. Unpublished text, 2009.

27 J. Belich, Replenishing the Earth, Oxford, 2009.

28 V.R. Lea, Book review of Mau Moko: The World of Maori Tattoo by N. Te Awekotuku and L.Waimarie Nikora (Auckland, 2007), in Mana,15, 2 (2009), www.scielo.br/scielo .php?script=sci_arttext\&pid=S0104-93132009000200014\&lng=en\&nrm=iso\&tlng=pt, accessed 18 August 2011.

R. Walker, 'Identidade e Antropologia Maori na Nova Zelândia', interview by Yara Schreiber in Mana, 3, 1 (1997), pp.169-78.

29 www.globalresearchalliance.org, accessed 18 August 2011.

30 W.C. Kim, and R. Mauborgne, Blue Ocean Strategy, Cambridge MA, 2005.

31 Unfortunately, I can only draw on interviews, there is no survey data available to verify this point. 
Journal of New Zealand Studies 